\title{
John Graham Ramsay
}

From his early studies of the complex geome-
try of a superimposed folding system to his demon-
stration of the importance of mathematical, me-
chanical, and geomerrical techniques in the study of
the origin and deformational conditions of rocks,
John G. Ramsay has been one of the most influen-
tial personalities in structural geology in the last 40
years. He is profiled herein in commemoration of
his 60th birthday in 1991 . (Ed.)

The world scientific community commemorated in 1991 the 60 th birthday of John G. Ramsay. Modern structural geology is indebted to him for various revolutionary innovations in diverse analytical developments. These were achieved along with the introduction of mathematical, mechanical, and geometrical techniques in the study of the origin and deformational conditions of the materials constituting the Earth's crust.

Bom on June 17, 1931, he had his first contacts with geology during World War II, when as a keen Boy Scout along with other children in the United Kingdom, he helped the war effort by touring his district in order to locate waste paper. From people dismembering and contributing their personal libraries, he rescued books like "Geology" by Charles Bird and "Let's Go Climbing!" by C.F. Kirkus, which he bought with his pocket money. These books set the scene for some time. Later, while climbing in northern Wales in close contact with the steep volcanic rocks of Moel Tryfan and the pillow lavas of Devil's Kitchen, he began what has proven to be a long and highly productive relationship with the Earth.

In 1949 he entered the Imperial College of Science and Technology in London on a royal fellowship. Here he received extraordinary inspiration from geologists having the stature of Gilbert Wilson and H.H. Read, who exerted a profound influence on the mind of the young Ramsay. This was especially significant in those times at the end of the 1940s, when many universities offered only limited concepts on folding and faulting as a mere complement to stratigraphy and petrology. Wilson and Read, however, included in their lectures the concepts on cleavage, lineations, and strain ellipsoids on one hand and granitization on the other. These attracted John's attention and became a challenge to him. He also was one of the few privileged, along with the students of Arthur Holmes in Edinburgh, to come into contact with the controversial idea of continental drift. which paved the way to the birth of the plate tectonics theory.

During a heated discussion between E.E. Bailey and Read in Edinburgh on the Precambrian geology of the Scottish Highlands, he became involved with his future doctoral research. The original location at Gleneig belonged to Professor C.E. Tilley and thus to Cambridge University. Therefore, Ramsay, John Sutton, and Janet Watson decided that the second best Lewisian inlier of Precambrian gneisses, which was at Loch Monar and Glen Strathfarrar, was to be his study area.

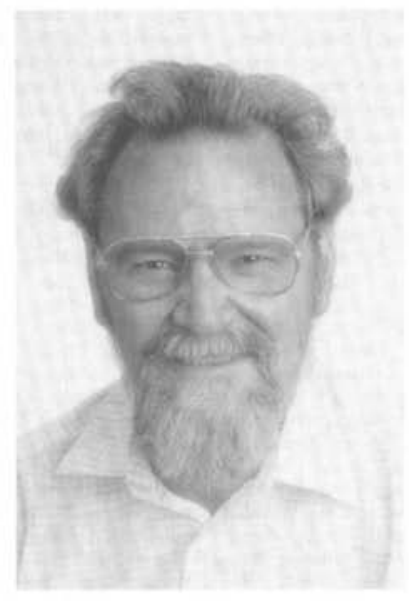

Once there, Ramsay was forced to decipher the complex geometry of a superimposed folding system, the likes of which nobody had faced before. As the end result of his analytical battle against the intricate interference patterns, presently known as the Ramsay patterns, he presented, after his first season of fieldwork, a series of strange sketches of outcrops showing circular and elliptical bedding traces that had almost unbelievable complexities. The reactions of his fellow students were full of disapproval and included accusations of his having drawn the surface markings of lichens and suggestions that he just draw the wooden tabletop at the bothy where he lived.

Now all who have visited those fantastic outcrops at the end of Loch Monar are convinced that the Ramsay patterns are real. No less important was the influence that the place itself exerted on him. To quote his own words. "Their aesthetic appeal, the forms of these natural complex patterns are as beautiful and geometrically satisfying as anything I have ever seen." After 2 years at Monar, he obtained his doctorate in 1954 and then got an extension for a further year of work at the sacred place of Glenelg. Here he proved that Bailey was right, that the Lewisian and Moinian Precambrian rocks were totally different groups of rocks. In addition, the experience at Loch Monar was very useful because Glenelg presented three phases of superposed folding.

The man, the scientist, cannot escape his responsibilities to the society that has forged him. When Ramsay undertook his National Service from 1955 to 1957 in the Corps of Royal Engineers, he elected to do it as a musician rather than as an officer. He took advantage of the scarcity of cellists and combined this with drums in parades, although he chose geology instead of music at the end of this short but happy stage. 
Back at the Imperial College as an instructor, he continued his work in Scotland with great professional satisfaction. Later on, he was offered the chance to go on a field excursion led by Professors Trümpy and Wenk to the Alps in the company of a group of distinguished geologists. The Alpine environment became an irresistible temptation for one whose mayor scientific passion is to unravel geologic structures and to reveal their geometry and architecture. While Wenk supported his work during the next summers by encouraging him and providing otherwise unobtainable maps, "other Swiss informed me that I was a trespasser in their mountains and was not welcome. I won enough support to be offered a position at ETH [Eidgenössische Technische Hochschule, Zürich] and University of Zürich, so now with the Alps at my doorstep for geology in the summer and skiing in the winter I am very content."

Professor Ramsay has been one of the more influential personalities in structural geology in the last 40 years. He has been a true heir and transformer of the legacy of Read, Wilson, Bailey, Holmes, Sutton, and other well-known and respected tectonicians of the British school. His first research in the Central Highlands amplified its range and generated other investigations. Indeed, it built a new scope and mentality in the philosophy of structural analysis. He demonstrated the importance of both the geometrical aspects and a solid base in the understanding, measurement, and mathematical description of the strain variations in rocks. The importance of the comprehension of such concepts and their applicability to tectonic evolution in other geologic environments, like the Swiss and French Alps, also proved to be a valuable research tool. The same importance applies to his philosophy embracing the principle that research on structural geology must be based on what actually happens to real rocks that then are treated with the necessary mathematical techniques. Rationality has a first order in his methodology, and this prevents the progression of polyphasic deformation to the infinite. He cautions that a hand specimen can not always be of regional significance, but he always remembers Ernst Cloos' quote that "every structure in a rock is significant, none is unimportant, even if, at first sight it may seem irrelevant."

The appearance in 1967 of his famous book "Folding and Fracturing of Rocks," translated into Spanish and Chinese, culminated years of dedication and toil that laid the foundations of modern structural geology. A new creative stage developed in the 1970 s when he published together with Rod H. Graham the paper "Strain Variation in Shear Belts" in the Canadian Journal of Earth Sciences (1970, v. 7. p. 786-813). They used X-rays in fabric analysis and chemical analysis in order to determine the relationships between physical and chemical modifications of erystals during their strain histories. This work had a positive historic impact on the field and became a reference point for later related research. The same mention is due to articles like "The Crack-Seal Mechanism of Rock Deformation" (1980. Nature, v. 284, p. 135-139) and "Rock Ductility and Its Influence on the Development of Tectonic Structures in Mountain Belts" (in "Mountain Building Processes," 1982, edited by K.J. Hsü, p. 111-127), In 1983 he published with Martin Huber the first volume of "Techniques of Modern Structural Geology," and volume two came out in 1987. The objective of this fundamental endeavor is the analysis of strain, folding, and faulting.

Besides these and many other specialized publications, surpassing 70 in number, the pedagogic qualities of John Ramsay are many. His lectures and conferences always are imbued with radiant intellectual energy, intelligibly transmitted through clear discussions and full of geological logic, and they are accompanied by his own illustrations, pictures, and diapositives. He balances professional expertise with the inspirational beauty that he discovers in nature and science. His contributions to science have been conveyed through the organi- zation of technical meetings, editorial work, and the creation of the Tectonic Studies Group in the United Kingdom.

The range of his research has been very wide, from the Caledonides in Scotland to the Himalayas, through the western Alps and southern Africa. He has shed new light on plate tectonics by providing new techniques for the interpretation of deformed belts. His characteristic rationality has warned that "today there is an unfortunate tendency of some of our earth sciences colleagues to put all their eggs into the plate tectonics basket and to consider phenomena on a smaller scale to be trivial details, irrelevant, or even obstructive to scientific progress. To our way of thinking this idea of "bigger is better' is intellectually and philosophically unacceptable."

As an academic at the universities of Johannesburg, Berkeley, Columbia, Leeds, Ontario, ETH-Zürich. California Institute of Technology, Azad Jammu, and Kashmir, he has enriched these institutions with his proposals and discussions on his geometrical and mathematical models. Based on the structures observed in the rocks, his methodologies include procedures for the evaluation of strain in fossils and the emplacement mechanisms of granitic diapirs.

The Imperial College, the Geological Society (UK), la Société Géologique de France, Geologische Vereinigung (Germany), the Geological Society of America, and the American Geophysical Union have distinguished him with awards and medals on several occasions. The Université de Rennes conferred on him the doctorate "Honoris Causa." He is an active member of many societies such as the Geologists' Associations of London, Yorkshire, Zurich, Switzerland, Academia Europaea, and Germany, as well as the U.S. National Academy of Sciences. His important participation in the $\mathrm{Na}$ tional Environment Research Council in the United Kingdom certainly is laudable, as is his former participation in the Commission on Tectonics of the International Union of Geological Sciences (IUGS).

His desire to project the principles and possibilities of the applications of structural geology to new horizons has propelled him to become a founding member of the editorial boards of Tectonophysics, Precambrian Research, and the Journal of Structural Geology.

This is a brief collage of the trajectory of a rigorous structural geologist, musician, and photographer, who writes poetry when he is modeling tectonic architecture. His personal, academic, and professional examples have inspired many geologists throughout the planet. To commemorate Ramsay's 60th birthday, these geologists organized a scientific forum held from 9 to II September 1991 at the Geologisches Institut, ETH, Zurich, entitled "The Geometry of Naturally Deformed Rocks, the John Ramsay Meeting."

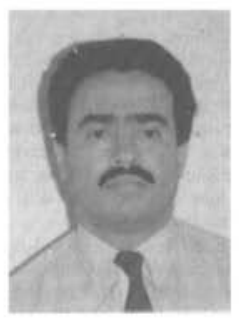

Allan López is President of the Costa Rican Geological Society (Colegio de Geólogos de Costa Rica) and a Lec. turer in Structural Geology and Tectonics at the Central American School of Geology, University of Costa Rica, where he studied before graduation from the International Institute for Aerial Surveys and Earth Sciences (I.T.C.) and Leiden University in The Netherlands. He is Chief of the Geological Coordination Office in the Costa Rican Energy and Communications Institute, Instituto Costarricense de Electricidad (I.C.E.) and has been elected a member of the IUGS Commission on Tectonics. 


\section{Nonrenewable Resources}

An Official Journal of the International Association for Mathematical Geology

Published by

Oxford University Press

Editor-in-Chiet

Richard B. Miccamenon

Deputy Editor

Micheel E. Hohn

\section{Book Review Editor}

Charles D. Masters

Editorial Assistant

Afleen V. Michelitch

\section{Advisory Board}

Frederik P. Agterberg

Geclogical Sunver of Canuda

\section{F. Barthel}

Federal institute for

Geosciences and

Nutural Resources.

Germany

Robert L. Bates

Eneritus,

Ohio State University.

USA.

Spero Curras

Carras Mining and Associatex. Autrals

Tirnotily C Coburn

Merathon Oil Company.

USA.

1.M. Coudert

Bureau de Richerches

Geologiqued et Minieres.

France

iohn H. Deroung, if. U.S. Geological Survey

Rao 5, OWh

Osmania University. ndia

Lamrence) Drew

US. Geologial Survery

Kim $\mathrm{H}$ tsbensen

Center for industrial Research

nomar

DonsidL Everhart

Corisulting Geologst

USA

Warrent Finch

US, Geological Suivey

David I. Forman

Burnau of Mineral Resources. Geology and Geophyic: Australia
Gabor Gasl

Hungarian Geological Sunvey

John D Grace:

ARCO, USA

Mario Gonther

Bundesanstatt for

Geomissenschaften und Rohistoffe. Germary

Thomas M. Gunthet

U.S. Bureacu of Mine

Jan Hartf

Zentralinstitut fur Phocix der Erde. Germany

Deverie Harmo

University of Acizons, US.A

Ryoichi Kouda

Gedogical Survey of Japan

Velio A Kunsiras

Advanced Resources international.

inc, U.S.A.

Brian W. Mackenzie

Centre far Resource Studiex

Cansda

Gemene Mctaren

Ministry of tnergy, Mines and

Petroleum Resources:

British Columbia, Canada

Zheo Pengda

China Univerity of Geoscences.

Wukin, PRC

Sonke Rehder

Bundesarstait for

Geowisenschatten und Rohstoffe.

Germany

danet5 sichs

US. Geolegical Survey

Alan Shapiro

Vukcan Materiak Company.

USA

Yothihiko Shimazaki

Nikno fryioration and

Develogment Company. Ltd. lapan

Richard Sinding-larser

Geologisk institutt, Norwzy

Donaid A Singet

US Gedogical Survey

Wiltarn a. Sat

Emory University, U.SA.

Wolfdietrich Skala

Free Unveryiat Beflin

Carlismith

West Virgina Geological Sunvey.

USA.

Thomask Wignall

Unverity of Guam
Are we using up our resources so fast that they will soon be exhausted? How can we avoid environmental damage when exploring for, developing. and marketing new and old resources? How useful have past resource assessments been for formulating public policy?

Over the past decade these and other critical issues in the field of nonrenewable resources have been the subject of increasing scientific debate. Quantitative assessments in particular have gained greater recognition among managers and planners in both public and private sectors. To address the needs of those concerned with nonrenewable resources throughout the world, beginning in 1992 Oxford University Press will publish Nonrenew. able Resources, an official journal of the International Association for Mathematical Geology.

Nonrenewable Resources will be broad-based and will cover both empirical and theoretical approaches. The editors will construe the field to include mineral and energy exploration, resource assessment, and the economics of resource supply, recovery restoration, and conservation. Studies will report on the whole range of nonrenewable resources, including metals, nonmetals, coal, oil, gas, geothermal energy, and uranium. Papers will emphasize multidisciplinary studies focused on land-use policy, domestic and international supply issues, and mineral and energy exploration planning.

A forum on current topics in nonrenewable resources will be featured in each issue. Questions explored will include

now are energy-and mineral-resource assessments performed?

Who are they for? How effective are they?

- Is fresh water becoming a nonrenewable resource?

- Should endangered species be considered nonrenewable resources?

a Should we assess the world's energy and mineral resources at 10-year intervals as we do in the census of the world's population?

- How have advances in recycling redefined "nonrenewable"?

\section{Member Order Form}

Di would like ta become a menber of the intemational Association for Mathernatical Geology for 1992. In addition to frewsletters and information concerning meetings, I understand i will receive a oneyear subscription (4 issues) to Nanrenewabie Resources.

DRegular Membenhip 545.00

Doutside U5: $\cdot 555.00$

- Price indudes aifexpedited delinery Prices quoted are in US. dollan.

Name

Addresi

Sityistatehip

Prity Press, 2001 Evans Road,

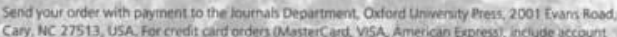

Cary, NC 27513, USA, For credit card order 